\title{
Modeling the Factors Enhancing the Implementation of Green Procurement in the Pakistani Construction Industry
}

\author{
Shabir Hussain Khahro ${ }^{1, *(1)}$, Aftab Hameed Memon ${ }^{2}$, Nafees Ahmed Memon ${ }^{3}$, Ali Arsal ${ }^{3}$ \\ and Tauha Hussain $\mathrm{Ali}^{3}$ \\ 1 Department of Engineering Management, College of Engineering, Prince Sultan University, \\ Riyadh 11586, Saudi Arabia \\ 2 Department of Civil Engineering, Quaid-e-Awam University of Engineering, Science and Technology, \\ Nawabshah 67450, Pakistan; aftabm78@gmail.com \\ 3 Department of Civil Engineering, Mehran University of Engineering and Technology, \\ Jamshoro 76062, Pakistan; nafees.memon@faculty.muet.edu.pk (N.A.M.); aliarsalarbab144@gmail.com (A.A.); \\ pvc@admin.muet.edu.pk (T.H.A.) \\ * Correspondence: shkhahro@psu.edu.sa
}

Citation: Khahro, S.H.; Memon,

A.H.; Memon, N.A.; Arsal, A.; Ali, T.H. Modeling the Factors Enhancing the Implementation of Green Procurement in the Pakistani Construction Industry. Sustainability 2021, 13, 7248. https://doi.org/ $10.3390 /$ su13137248

Academic Editor: Alberto Giretti

Received: 3 June 2021

Accepted: 17 June 2021

Published: 29 June 2021

Publisher's Note: MDPI stays neutral with regard to jurisdictional claims in published maps and institutional affiliations.

Copyright: (c) 2021 by the authors. Licensee MDPI, Basel, Switzerland. This article is an open access article distributed under the terms and conditions of the Creative Commons Attribution (CC BY) license (https:// creativecommons.org/licenses/by/ $4.0 /)$.

\begin{abstract}
This paper adds to the existing body of knowledge on green procurement approaches and sustainability theories for procurement management. It provides practical factors that can directly help the practitioners in implementing green procurement in construction projects. Green procurement is a new era in the construction industry of Pakistan. Thus, this paper aims to quantify the factors improving the adoption of green procurement in construction projects. A detailed literature review has been conducted to design and develop a conceptual model for green procurement. The study intricates the perception of 77 experienced practitioners involved in handling construction projects. The model was analyzed and validated with a partial least squares structural equation modeling technique with SmartPLS V3 software. The model results indicate that market factors and techniques play an essential role in enhancing green procurement acceptance and adoption. This study highlights the gap in achieving sustainability and controlling the environmental impacts caused by construction activities. It assists the construction practitioners to implement the green procurement for better environmental and sustainable performance.
\end{abstract}

Keywords: green procurement; construction; PLS-SEM; structural equation modeling; Pakistan

\section{Introduction}

The construction industry improves the social and economic values of any country. It promotes the achievement of essential living needs, such as lodging, infrastructure, and job creation $[1,2]$. However, critics express displeasure due to the various problems caused by this industry. It has been reported that it impacts the environment and natural resources. Ref. [3] pointed out that one of the main problems caused by construction works is the emission of higher greenhouse gases (GHG). The construction industry depends on nonrenewable resources; thus, various raw materials affect the environment significantly [4].

Economic growth is a vital aspect of the development of any country. Economic growth highly depends on the business and performance of several industries. The construction industry is an important industry that contributes to economic development and helps in enhancing social development by providing the required infrastructure for living and jobs. However, the construction industry has verse effects, such as higher energy usage, especially the non-renewable energy that is needed for material transportation, construction, and maintenance [5,6]. Construction projects also utilize a massive amount of natural resources [7], resulting in air pollution and greenhouse gases.

Due to urbanization, the building projects are increasing and resulting in several problems. Construction activities require vast quantities of natural resources, in particular 
concrete produced in large quantities. The transport and manufacturing of construction materials consume a higher amount of energy and after construction work finishes, occupants also consume energy in the form of electricity [8]. Statistical data of 2010 revealed that construction activities consume approximately $45 \%$ of the world's energy. Building projects are reported to produce greenhouse gases, generate solid waste, polluting water and air [9]. Various environmental problems need serious attention in this industry and it can be resolved with the adoption of suitable approaches such as green procurement.

Such issues can be controlled through the adoption and implementation of sustainable practices and principles [10-12]. Green sustainability practices have become a very fundamental need of all industries, including the construction industry $[13,14]$. suggested that green procurement is the best solution for reducing environmental issues. The concept of green procurement is the integration and implementation of environmental friendly practices throughout the different phases of the construction project life cycle [15]. The implementation of green procurement can benefit the construction industry by depressing energy consumption, increasing the performance and durability throughout the life cycle and protects the natural resources [12]. It is an efficient method to address environmental concerns and issues on any project [16]. It helps the stakeholders to enhance the sustainable practices on projects [17]. In terms of environmental advantages, green procurement has various other advantages, decreases pollution, and enhances the culture of using recycled materials [18].

In Pakistan, the construction industry is progressing and has an optimistic influence on its economic development. The construction industry contributed $4.7 \%$ in GDP in 2016, which increased to 5.2\% in 2017. According to a World Bank report, the ChinaPakistan economic corridor is one of the key reasons for economic growth [19]. However, at the same time, higher construction activities utilize fuel, energy, natural resources, waste generation, and environmental degradation. Therefore, it is necessary to make arrangements to improve construction practices [20]. Improving the quality of construction and limiting its adverse effects will improve project performance. Green procurement is used worldwide to improve construction practices. It is an effective method to improve environmental performance globally [21]. It is the essential component of the green supply chain system and is considered the first step towards sustainable construction. Improving financial and environmental performance is assured through green procurement [22]. It promotes a green supply chain to ensure that environmental friendly materials are used in the buildings [17].

It has been reported that green procurement is very effective in reducing the environmental impacts of the construction material supply chain. It helps in better financial and environmental performance [5]. However, it involves the active participation of all stakeholders [10]. Green procurement has shown positive results in various countries [23,24]. Green procurement in the building sector is gaining popularity due to its results, but the process is slow in developing countries, including Pakistan. Therefore, it is necessary to take green procurement in the loop and apply its practices to improve construction project performance. This study examines the key factors that will promote the adoption of green procurement in the construction industry of Pakistan.

\section{Literature Review}

Identification of critical factors to promote green procurement in the construction industry is very challenging. Various researchers have proposed diverse methods for implementing and adopting green procurement in construction projects [25]. Increasing the knowledge of green procurement among practitioners can play a significant role [26]. This can be achieved through (i) education, (ii) case studies, (iii) preferment, (iv) best practices and rewards. Organizational policies can play a vital role in this regard. Another critical aspect is the effective collaboration and cooperation between vendors and clients [5]. Stakeholder involvement, requirements and legislation, corporate factors, public feedback, 
principles, and other related factors could significantly improve the adoption of green procurement [18].

The Romanian Green Building Council reported that green materials are more accessible to implement than traditional materials, with various benefits, including the reduction in carbon footprint by approximately $40 \%$ [27]. In addition, it is beneficial for conserving energy-generating resources and protecting the environment [28]. The adoption of green initiatives can be encouraged by policymakers and legislators [29-31]. The adoption of green procurement can also contribute to the success of the business plans [32].

Green procurement can be improved by increasing the awareness and interest of the stakeholders [33]. The actual benefits of green procurement can only be achieved if stakeholders are involved in building projects throughout the project lifecycle with mutual understanding and commitment $[14,30]$. Designers, such as architects and engineers, can facilitate green procurement [34-36]. Corporate environmental vision [31], support for midlevel management staff [14,31], environmental awareness among practitioners [5], training of staff on green procurement [14], and the variation of competitors and consumers [37] play an essential role to promote the green procurement. Several factors can enforce green procurement, as highlighted by various researchers [14,38]. These factors can succeed if the organizations change their culture to choose the environmental friendly and reused material. The vendors should adequately communicate information of the green materials to buyers [38]. The materials should also be selected based on their potential reuse and recycle opportunities [14,30,31]. A review of the literature published worldwide has been added and summarized in Table 1.

Table 1. Mapping of factors enhancing the adoption of green procurement.

\begin{tabular}{|c|c|c|}
\hline No. & Factors & Source \\
\hline 1. & Government and non-government organization's demand. (e.g., green label scheme) & {$[5,16,18]$} \\
\hline 2. & Environmental regulation made obligatory by Government & {$[16,18,22,30,39]$} \\
\hline 3. & $\begin{array}{c}\text { Formation of standards (e.g., evaluation criteria, green specification, suppliers' ISO } 14000 \\
\text { certification) }\end{array}$ & {$[5,14,16,18,22,30,39]$} \\
\hline 4. & Requirements of the client in the tender & {$[16,18,22,30]$} \\
\hline 5. & Stakeholders' mutual understanding between themselves on green procurement & {$[5,18,30]$} \\
\hline 6. & Stakeholders' mutual commitment between themselves on green procurement & {$[4,14,18,22,30,39]$} \\
\hline 7. & Compliance, monitoring and audit on suppliers & {$[18,22]$} \\
\hline 8. & Cooperation with stakeholders regarding the environment & {$[5,16,18,30,39]$} \\
\hline 9. & Corporate environmental vision & {$[14,16,18,22,30]$} \\
\hline 10. & Commitments by Executive management & {$[14,18,22,30,39]$} \\
\hline 11. & Mid-level managers' support & {$[14,18,22]$} \\
\hline 12. & Business benefits understood properly & {$[14,18,22]$} \\
\hline 13. & Staff training/green procurement program and sustainability policy by organization & {$[5,14,16,18,30,39]$} \\
\hline 14. & $\begin{array}{l}\text { Key staff's incentive programs and implementation of green procurement goal to the } \\
\text { job description }\end{array}$ & {$[16,18,22,39]$} \\
\hline 15. & $\begin{array}{l}\text { Availability of sustainability expertise and dedicated resources to support green procurement } \\
\text { and decision making }\end{array}$ & {$[5,14,18,30,39]$} \\
\hline 16. & Coordination within the department. (e.g., sustainability expertise and procurement staff) & {$[5,14,18,22,39]$} \\
\hline 17. & System of continuous review, monitoring and tracking & {$[5,18]$} \\
\hline 18. & International trends (e.g., customer awareness) & {$[5,14,16,18,22,30]$} \\
\hline 19. & Strategies adopted by competitors & {$[16,18,22]$} \\
\hline
\end{tabular}


Table 1. Cont.

\begin{tabular}{|c|c|c|}
\hline No. & Factors & Source \\
\hline 20. & Strategies adopted by affiliated companies & [18] \\
\hline 21. & Strategies adopted by other progressive companies. (within or outside your sector) & {$[16,18,39]$} \\
\hline 22. & Schemes adopted by government (e.g., Housing Authority) & {$[5,16,18,30,39]$} \\
\hline 23. & Green product's information should be available from a reliable database & {$[18,30,39]$} \\
\hline 24. & According to specifications, potential information from suppliers should be adopted carefully & {$[5,18,22,30]$} \\
\hline 25. & Demands of green characteristics for performance-based specification should be clear & {$[16,18,39]$} \\
\hline 26. & Green technology for construction purpose should be available & {$[5,14,18,22,30]$} \\
\hline 27. & Project's adequate life cycle should be considered & {$[5,18]$} \\
\hline 28. & Selection of materials according to their recyclability & {$[14,18,22,30]$} \\
\hline 29. & Selection of materials according to their low risks to the environment & {$[5,18,22,30,39]$} \\
\hline 30. & $\begin{array}{l}\text { For assessment of building's green performance, facilities of cross-reference should be available } \\
\text { (e.g., BEAM-Plus) }\end{array}$ & {$[16,18]$} \\
\hline 31. & Model clauses of green specifications should be available & {$[14,16,18]$} \\
\hline 32. & Green procedures or practices should be adopted. (e.g., waste management) & {$[5,14,18,22,30,39]$} \\
\hline 33. & Product's design according to its less consumption of material or energy & {$[14,16,18,22,30]$} \\
\hline 34. & Designing products from recycled or reused material & {$[14,18,22,30]$} \\
\hline
\end{tabular}

A pilot study was conducted to evaluate the factors before measuring their influence to boost green procurement in the construction industry. Unstructured interviews were conducted from seven experienced practitioners with higher and relevant experience in the construction industry. Three responses from contractors, two representatives from consultants, and two representatives from clients were added to the panel of experts. Based on the expert feedback, a final set of questionnaires was designed to seek the experts feedback on critical factors supporting the adoption of green procurement.

\section{Research Methodology}

\subsection{Data Collection and Analysis Methods}

Data collection was done through a questionnaire survey. This survey aimed to understand the experts' perception regarding the factors that can support improving the implementation of green procurement in the construction project of Pakistan. In total, 35 factors identified from the literature were investigated to assess their significance through a 5-point Likert scale; $01=$ not significant, 02 = slightly significant, $03=$ moderately significant, $04=$ very significant, and $05=$ extremely significant. Questionnaire forms were randomly distributed amongst experts working with contractors, consultants, and clients on ongoing construction projects. The data have been analyzed using (i) factor analysis and (ii) structural equation modeling. Factor analysis classifies the variables based on the mutual inter-relationship [40]. Statistical package for Social Sciences (SPSS) was used for performing factor analysis tests in this research work.

On the contrary, the relationship between the unobserved variable, named as latent variables and observed variables named as measured or manifest variables, is assessed with structural equation modeling (SEM). The influence of design-related risk on the performance of the design-build project with SEM application was evaluated by [41]. The effect of service quality on client satisfaction level in Cambodia was also assessed with the help of SEM [42]. SEM in evaluating the significance level of the factors affecting project cost in large construction projects of Malaysia is applied by [43]. A bid decision-making model with the help of SEM was developed by [17]. SEM became successful because it is a flexible technique [44] and it can accommodate both large and small sample sizes [45]. 


\subsection{Survey Statistics and Demography of the Respondents}

Questionnaires were distributed to 120 experienced professionals in the construction industry, where only 85 practitioners responded successfully. Among these questionnaires, only 77 responses were considered for data analysis, where 8 questionnaires were dropped due to incomplete data. Among the collected questionnaires for analysis, 30 responses were from contractors, 25 responses were from consultants, and 22 responses were from the client. The details are shown in Table 2.

Table 2. Demographic information of the respondents.

\begin{tabular}{|c|c|c|}
\hline Description & Frequency & Percentage \\
\hline \multicolumn{3}{|l|}{ Academic Qualification } \\
\hline Bachelor of Engineering (B.E) & 45 & 58.4 \\
\hline Diploma & 12 & 15.6 \\
\hline $\begin{array}{l}\text { Bachelor of Technology } \\
\text { (B.Tech) }\end{array}$ & 1 & 1.3 \\
\hline Master of Philosophy (M.Phil) & 1 & 1.3 \\
\hline Master of Engineering (ME) & 18 & 23.4 \\
\hline \multicolumn{3}{|l|}{ Size of Projects } \\
\hline Above 10 Million Rupees & 71 & 92.2 \\
\hline Less than 10 Million Rupees & 6 & 7.8 \\
\hline \multicolumn{3}{|l|}{ Experience } \\
\hline Less than 10 years & 35 & 45.46 \\
\hline 10 to 20 Years & 23 & 29.87 \\
\hline Above 20 Years & 19 & 24.67 \\
\hline \multicolumn{3}{|l|}{ Working Position } \\
\hline Managerial Level & 23 & 29.87 \\
\hline Engineering Level & 31 & 40.26 \\
\hline Planners & 8 & 10.39 \\
\hline Directors & 15 & 19.48 \\
\hline
\end{tabular}

The majority of the respondents have engineering degrees. A significant number of the respondents (i.e., $92.2 \%$ ) are engaged in projects with a minimum contract cost of 10 million rupees. Among these participants, 35 of 71 have working experience of up to 10 years (with minimum experience of 6 years), while 42 respondents have working experience of more than 10 years. Among these respondents, $40 \%$ of respondents work at the engineering level (such as project engineer, site engineer), $29.87 \%$ of respondents possess managerial designation, including project manager, construction manager, and contract management. Further, $19.8 \%$ of respondents are directors of their respective organizations, and $10.39 \%$ of the respondents work as planners in construction organizations.

The respondents were also requested to share the extent of green procurement requirements in the building industry. In total, 50 respondents indicated that green procurement is highly required, 24 respondents said it is moderately needed. In comparison, only 3 respondents mentioned that there is no need for green procurement in construction projects of Pakistan. Further, $48.1 \%$ of the respondents said that they apply green procurement rarely in their projects. In contrast, $46.8 \%$ of the respondents used green procurement at a moderate level and only $5.2 \%$ of the respondent mentioned that they mainly apply green procurement. 


\subsection{Categorization of the Factors}

Factors analysis for this study was used to sort out and categorize inter-related factors enhancing the adoption of green procurement. Categorization of the factors was done through factor analysis to identify groups with inter-related parameters [46]. A KaiserMeyer-Olkin measure of sampling adequacy for gathered data was found as 0.800 , which was higher than the minimum required value of 0.6 as suggested by [46]. Additionally, Barlett's test of sphericity has significance at 0.000 , which showed that the correlation matrix is not an identity matrix. Generated results from principal components analysis and rotations converged in 11 iterations, rotated component matrix indicated that the factors are classified in 5 categories with $76.21 \%$ of variance accounted as in Table 3 .

Table 3. Component matrix (Rotated).

\begin{tabular}{|c|c|c|c|c|c|}
\hline \multirow{2}{*}{ Variables } & \multicolumn{5}{|c|}{ Component } \\
\hline & 1 & 2 & 3 & 4 & 5 \\
\hline $\begin{array}{l}\text { Formation of standards (e.g., evaluation criteria, green specification, suppliers' ISO } \\
14000 \text { certification) }\end{array}$ & 0.789 & 0.134 & 0.041 & 0.112 & -0.021 \\
\hline Requirements of the client in tender & 0.777 & 0.113 & -0.063 & 0.309 & 0.088 \\
\hline Government and non-government organization's demand (e.g., green label scheme) & 0.706 & 0.051 & 0.369 & 0.055 & 0.334 \\
\hline Green procedures or practices should be adopted (e.g., waste management) & 0.696 & 0.375 & 0.229 & 0.028 & 0.152 \\
\hline Designing products for recycling, reuse, component parts and recovery of material & 0.664 & 0.494 & 0.115 & -0.055 & 0.256 \\
\hline Stakeholders' mutual understanding between themselves on green procurement & 0.647 & 0.188 & 0.334 & 0.277 & 0.136 \\
\hline Environmental regulation made obligatory by Government & 0.589 & -0.006 & 0.365 & 0.365 & 0.117 \\
\hline Stakeholders' mutual commitment between themselves on green procurement & 0.558 & 0.193 & 0.331 & 0.003 & 0.448 \\
\hline Products being designed to alleviate or lower the environmental during construction & 0.383 & 0.726 & 0.044 & 0.125 & 0.099 \\
\hline Mid-level managers' support & 0.260 & 0.650 & -0.118 & 0.367 & 0.118 \\
\hline Green product's information should be available from reliable database & 0.072 & 0.615 & 0.120 & 0.615 & 0.326 \\
\hline Business benefits understood properly & 0.225 & 0.527 & 0.286 & 0.398 & -0.051 \\
\hline Selection of materials according to their recyclability & 0.177 & 0.510 & 0.187 & 0.287 & 0.262 \\
\hline Demands of green characteristics for performance-based specification should be clear & 0.289 & 0.505 & 0.361 & 0.197 & 0.219 \\
\hline Staff training/green procurement program and sustainability policy by organization & 0.322 & 0.474 & 0.146 & 0.167 & 0.226 \\
\hline Project's adequate life cycle should be considered & 0.107 & 0.179 & 0.743 & 0.230 & 0.185 \\
\hline Corporate environmental vision & 0.383 & 0.168 & 0.680 & 0.180 & 0.196 \\
\hline Green technology for construction purpose should be available & 0.134 & 0.358 & 0.678 & 0.314 & 0.087 \\
\hline Cooperation with stakeholders regarding the environment & 0.213 & 0.262 & 0.553 & 0.162 & 0.551 \\
\hline $\begin{array}{l}\text { According to specifications potential information from suppliers should be } \\
\text { adopted carefully }\end{array}$ & 0.076 & 0.242 & 0.532 & 0.354 & 0.258 \\
\hline Coordination within department (e.g., sustainability expertise and procurement staff) & 0.236 & 0.353 & 0.530 & 0.202 & 0.139 \\
\hline Commitments by Executive management & 0.455 & -0.021 & 0.519 & 0.270 & 0.327 \\
\hline Compliance, monitoring and audit on suppliers & 0.356 & 0.138 & 0.028 & 0.825 & 0.072 \\
\hline $\begin{array}{l}\text { For assessment of building's green performance, facilities of cross-reference should be } \\
\qquad \text { available (e.g., BEAM-Plus) }\end{array}$ & 0.242 & 0.222 & 0.412 & 0.722 & 0.084 \\
\hline Model clauses of green specifications should be available & 0.068 & 0.115 & 0.214 & 0.708 & 0.227 \\
\hline $\begin{array}{l}\text { Key staff's incentive programs and implementation of green procurement goal to } \\
\text { job description }\end{array}$ & 0.130 & 0.255 & 0.111 & 0.702 & 0.090 \\
\hline
\end{tabular}


Table 3. Cont.

\begin{tabular}{|c|c|c|c|c|c|}
\hline \multirow{2}{*}{ Variables } & \multicolumn{5}{|c|}{ Component } \\
\hline & 1 & 2 & 3 & 4 & 5 \\
\hline System of continuous review, monitoring and tracking & 0.010 & 0.145 & 0.221 & 0.513 & 0.194 \\
\hline $\begin{array}{l}\text { Availability of sustainability expertise and dedicated resources to support green } \\
\text { procurement and decision making }\end{array}$ & 0.404 & 0.342 & 0.377 & 0.439 & 0.257 \\
\hline Schemes adopted by government (e.g., Housing Authority) & 0.147 & 0.053 & 0.141 & 0.298 & 0.800 \\
\hline International trends (e.g., customer awareness) & 0.319 & 0.122 & 0.340 & 0.113 & 0.657 \\
\hline Strategies adopted by other progressive companies (within or outside your sector) & 0.344 & 0.278 & 0.144 & 0.186 & 0.619 \\
\hline Selection of materials according to their low risks to the environment & 0.104 & 0.474 & 0.193 & -0.119 & 0.617 \\
\hline Strategies adopted by affiliated companies & 0.117 & 0.483 & 0.187 & 0.305 & 0.616 \\
\hline Strategies adopted by competitors & 0.099 & 0.288 & 0.428 & 0.187 & 0.549 \\
\hline Product's design according to its less consumption of material or energy & 0.416 & 0.268 & 0.275 & 0.238 & 0.516 \\
\hline
\end{tabular}

Extraction Method: Principal Component Analysis. Rotation Method: Varimax with Kaiser Normalization. a. Rotation converged in 11 iterations. The relationship loading values are in bold.

It is observed that, from 35 variables, 2 variables have loading values below 0.5 which can be ignored. Hence, these two factors were omitted and the rest 33 factors were considered for further analysis. Analyzing the variables and their respective factors, the five constructs or groups were named as (i) government policies and stakeholder commitment (GPSC) with 8 variables, (ii) organizational support and knowledge (OSK) with 6 variables, (iii) corporate factors (CP) with 7 variables, (iv) industry awareness (IA) with 5 factors, and (v) market factors and techniques (MFT) with 7 variables. These five categories were used to develop a conceptual model. Manifest variables, variable codes, and individual construct names are shown in Table 4. The developed model is shown in Figure 1.

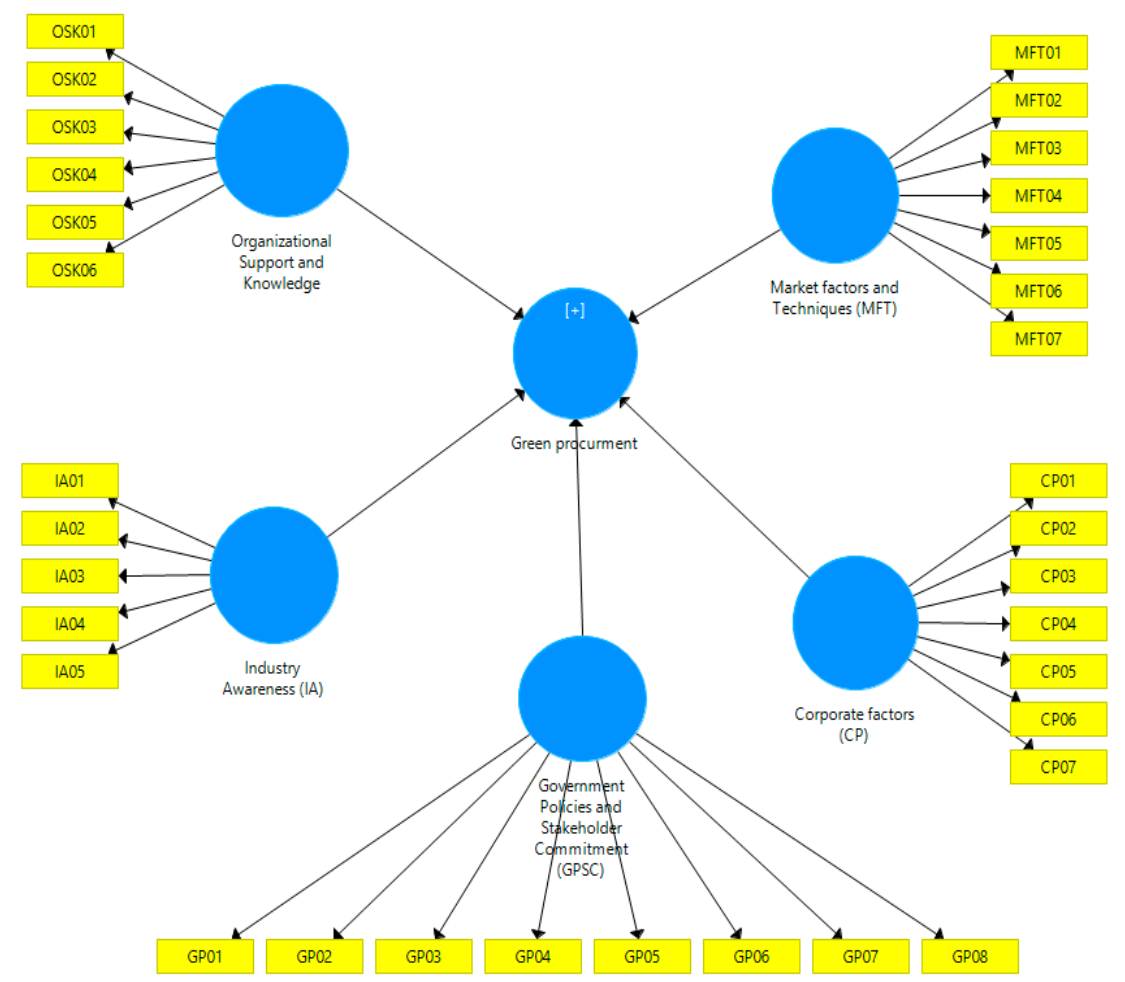

Figure 1. Conceptual Model. 
Table 4. Details of constructs and manifest variables.

\begin{tabular}{|c|c|c|}
\hline Construct & Factor Code & Factor Loading \\
\hline \multirow{8}{*}{$\begin{array}{l}\text { Government Policies and } \\
\text { Stakeholder Commitment } \\
\text { (GPSC) }\end{array}$} & GP01 & 0.789 \\
\hline & GP02 & 0.777 \\
\hline & GP03 & 0.706 \\
\hline & GP04 & 0.696 \\
\hline & GP05 & 0.664 \\
\hline & GP06 & 0.647 \\
\hline & GP07 & 0.589 \\
\hline & GP08 & 0.558 \\
\hline \multirow{6}{*}{$\begin{array}{l}\text { Organizational Support and } \\
\text { Knowledge (OSK) }\end{array}$} & OSK01 & 0.726 \\
\hline & OSK02 & 0.65 \\
\hline & OSK03 & 0.615 \\
\hline & OSK04 & 0.527 \\
\hline & OSK05 & 0.51 \\
\hline & OSK06 & 0.505 \\
\hline \multirow{7}{*}{ Corporate factors $(\mathrm{CP})$} & СР01 & 0.743 \\
\hline & СP02 & 0.68 \\
\hline & СР03 & 0.678 \\
\hline & СР04 & 0.553 \\
\hline & СР05 & 0.532 \\
\hline & СР06 & 0.53 \\
\hline & СР07 & 0.519 \\
\hline \multirow{5}{*}{ Industry Awareness (IA) } & IA01 & 0.825 \\
\hline & IA02 & 0.722 \\
\hline & IA03 & 0.708 \\
\hline & IA04 & 0.702 \\
\hline & IA05 & 0.513 \\
\hline \multirow{7}{*}{$\begin{array}{c}\text { Market factors and } \\
\text { Techniques (MFT) }\end{array}$} & MFT01 & 0.8 \\
\hline & MFT02 & 0.657 \\
\hline & MFT03 & 0.619 \\
\hline & MFT04 & 0.617 \\
\hline & MFT05 & 0.616 \\
\hline & MFT06 & 0.549 \\
\hline & MFT07 & 0.516 \\
\hline
\end{tabular}

\section{Results and Discussion}

The PLS model is tested in two phases: (1) measurement model and (2) structural model. Before the model results, it is essential to check the adequacy of the sample size. For robust PLS path modeling estimations, the sample size should be equal or larger than 10 times the largest number of structural paths directed at a particular construct in the inner path model [45]. From Figure 1, it is observed that, in this study, there are five structural paths which mean at least 50 samples are required for this analysis. Since the sample size in this study is 77, which is greater than the sample size needed. Hence, the data samples used for this analysis are adequate.

\subsection{Assessment of Measurement Model}

To ensure that the indicators and measurement variables used to quantify a specific construct are actually part of that construct is the critical reason to make a measurement model. It also confirms the model's dependability and the appropriateness of the relationship amongst the latent variables and measuring indicators. The validity of the measurement models represent the degree of the variables' interaction with their respective latent variables $[47,48]$. It also confirms the model's reliability, i.e., measurement instrument accuracy [49]. The overall measurement model is assessed by verifying (i) individual item reliability and convergent validity [50], (ii) discriminant validity of the model [48,51]. 
As determined by uniform variable loadings, the correlations between items and their respective latent variables define individual item reliability. The common cut-off point is that latent variables should account for $50 \%$ of the variance in an observed variable (i.e., the square of the loadings). As a result, indicators with outer loadings greater than 0.7 should be regarded as satisfactory $[52,53]$. Indicators with less than a 0.5 loading value can be avoided [54]. Convergent validity determines the degree of intrinsic accuracy of the metrics and their respective latent variables. This can be calculated by measuring composite reliability (CR) and average variance extracted (AVE) $[55,56]$. CR verifies the construct to validate its respective indicators, and the value of CR should be at least 0.6 [57]. The sum of the variance captured for the items of latent variable, i.e., AVE checks the construct's internal consistency. A minimum $50 \%$ of the variance must be preserved, i.e., AVE value must be at least 0.5 [45]. Table 5 shows the results obtained by PLS algorithm of the measurement model.

Table 5. Convergent validity of the model.

\begin{tabular}{cccc}
\hline Constructs & $\begin{array}{c}\text { Cronbach's } \\
\text { Alpha }\end{array}$ & $\begin{array}{c}\text { Composite } \\
\text { Reliability }\end{array}$ & $\begin{array}{c}\text { Average Variance } \\
\text { Extracted (AVE) }\end{array}$ \\
\hline Corporate factors (CP) & 0.886 & 0.91 & 0.592 \\
\hline $\begin{array}{c}\text { Government Policies and Stakeholder } \\
\text { Commitment (GPSC) }\end{array}$ & 0.92 & 0.934 & 0.64 \\
\hline Industry Awareness (IA) & 0.854 & 0.893 & 0.626 \\
\hline Market factors and Techniques (MFT) & 0.87 & 0.898 & 0.561 \\
\hline Organizational Support and Knowledge & 0.901 & 0.921 & 0.662 \\
\hline
\end{tabular}

The Cronbach's Alpha, composite reliability, and average variance extracted (AVE) values of all the constructs are above the cut-off value. This means that the constructs show a satisfactory level of strength in defining the adoption of green procurement. A discriminant validity test was also carried out to verify the degree to which every construct is different from other constructs [58,59]. Discriminant validity was assessed using two tests as (i) analysis of cross-loading and (ii) analysis of the average variance extracted by comparing latent variable correlations. Results of the cross-loading analysis are shown in Table 6.

Table 6 indicates that each construct's parameter has a higher loading than variables from other constructs. This verifies that all of the variables are consistent with their constructs. For absolute discriminant validity, each construct's AVE's square root should be greater than the correlation of two constructs [48]. For this, the diagonal correlation matrix is replaced with the square root of the AVE as shown in Table 7.

Table 7 shows that the diagonal elements in the respective rows and columns are higher than the off-diagonal elements, indicating that the construct has internal consistency, as suggested by [50]. 
Table 6. Analysis of cross-loadings of factors.

\begin{tabular}{|c|c|c|c|c|c|c|}
\hline Construct & Variable & $\mathrm{CP}$ & GPSC & IA & MFT & OST \\
\hline \multirow{7}{*}{$\mathrm{CP}$} & СР01 & 0.783 & 0.513 & 0.606 & 0.668 & 0.627 \\
\hline & СР02 & 0.754 & 0.616 & 0.484 & 0.569 & 0.523 \\
\hline & СР03 & 0.752 & 0.477 & 0.499 & 0.607 & 0.582 \\
\hline & СР04 & 0.788 & 0.554 & 0.488 & 0.576 & 0.634 \\
\hline & СР05 & 0.778 & 0.509 & 0.655 & 0.711 & 0.731 \\
\hline & СР06 & 0.772 & 0.607 & 0.633 & 0.697 & 0.709 \\
\hline & СР07 & 0.76 & 0.656 & 0.461 & 0.581 & 0.57 \\
\hline \multirow{8}{*}{ GP } & GP01 & 0.461 & 0.766 & 0.395 & 0.425 & 0.464 \\
\hline & GP02 & 0.458 & 0.783 & 0.324 & 0.439 & 0.469 \\
\hline & GP03 & 0.638 & 0.866 & 0.543 & 0.523 & 0.499 \\
\hline & GP04 & 0.428 & 0.751 & 0.506 & 0.516 & 0.537 \\
\hline & GP05 & 0.588 & 0.78 & 0.482 & 0.569 & 0.612 \\
\hline & GP06 & 0.697 & 0.864 & 0.632 & 0.684 & 0.646 \\
\hline & GP07 & 0.604 & 0.784 & 0.585 & 0.49 & 0.492 \\
\hline & GP08 & 0.663 & 0.8 & 0.568 & 0.635 & 0.587 \\
\hline \multirow{5}{*}{ IA } & IA01 & 0.49 & 0.616 & 0.841 & 0.613 & 0.535 \\
\hline & IA02 & 0.621 & 0.569 & 0.775 & 0.681 & 0.665 \\
\hline & IA03 & 0.638 & 0.446 & 0.683 & 0.658 & 0.641 \\
\hline & IA04 & 0.604 & 0.498 & 0.899 & 0.704 & 0.616 \\
\hline & IA05 & 0.601 & 0.413 & 0.741 & 0.648 & 0.601 \\
\hline \multirow{7}{*}{ MFT } & MFT01 & 0.606 & 0.419 & 0.499 & 0.671 & 0.484 \\
\hline & MFT02 & 0.584 & 0.569 & 0.551 & 0.794 & 0.558 \\
\hline & MFT03 & 0.645 & 0.607 & 0.6 & 0.78 & 0.665 \\
\hline & MFT04 & 0.562 & 0.489 & 0.674 & 0.722 & 0.589 \\
\hline & MFT05 & 0.666 & 0.463 & 0.619 & 0.805 & 0.724 \\
\hline & MFT06 & 0.716 & 0.528 & 0.744 & 0.857 & 0.684 \\
\hline & MFT07 & 0.576 & 0.579 & 0.587 & 0.617 & 0.501 \\
\hline \multirow{6}{*}{ OSK } & OSK01 & 0.573 & 0.58 & 0.51 & 0.527 & 0.766 \\
\hline & OSK02 & 0.692 & 0.522 & 0.431 & 0.601 & 0.754 \\
\hline & OSK03 & 0.644 & 0.443 & 0.578 & 0.671 & 0.806 \\
\hline & OSK04 & 0.686 & 0.571 & 0.664 & 0.754 & 0.838 \\
\hline & OSK05 & 0.704 & 0.546 & 0.624 & 0.641 & 0.833 \\
\hline & OSK06 & 0.716 & 0.618 & 0.727 & 0.726 & 0.878 \\
\hline
\end{tabular}

Table 7. Latent variable correlations.

\begin{tabular}{cccccc}
\hline Constructs & CP & GPSC & IA & MFT & OSK \\
\hline Corporate factors (CP) & 0.77 & & & & \\
\hline $\begin{array}{c}\text { Government Policies and Stakeholder } \\
\text { Commitment (GPSC) }\end{array}$ & 0.721 & 0.8 & & & \\
\hline Industry Awareness (IA) & 0.718 & 0.645 & 0.791 & & \\
\hline Market factors and Techniques (MFT) & 0.825 & 0.682 & 0.749 & 0.817 & \\
\hline Organizational Support and Knowledge & 0.819 & 0.679 & 0.748 & 0.806 & 0.814 \\
\hline
\end{tabular}

\subsection{Assessment of Structural Model}

The next step is to validate the SEM structural model after the measurements are accurate. Figure 2 shows the results of the Smart PLS model. 


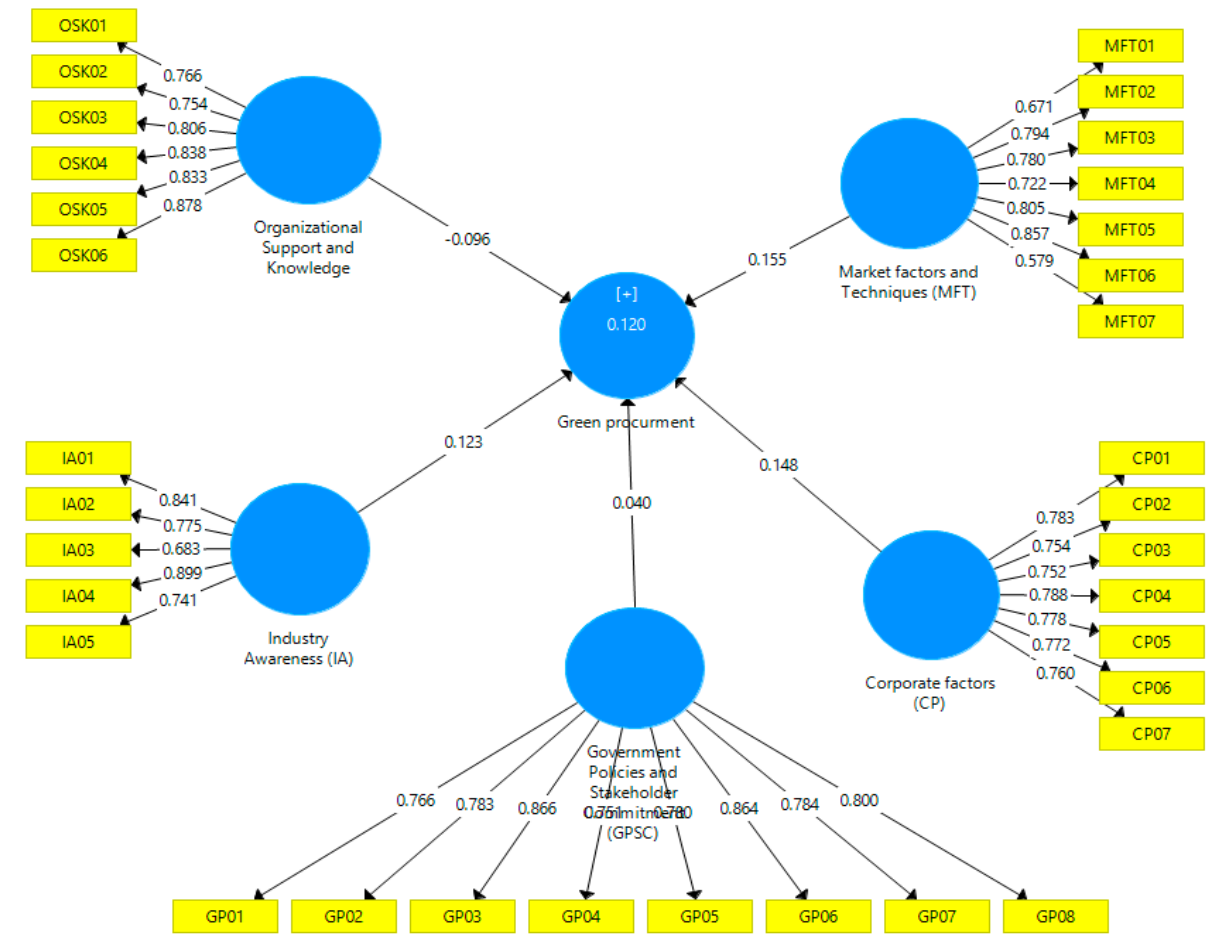

Figure 2. Result of PLS Model.

The $R^{2}$ value of endogenous is reported as substantial if it is equal or greater than 0.26 if its value is greater than 0.13 and less than 0.26 , the model is considered moderate and the model is deemed weak if $R^{2}$ value is 0.02 to 0.13 [60]. From Figure 2, it can be seen that the value of $R^{2}$ for the endogenous variable, i.e., adoption of green procurement, is 0.120 . This value specified that the explaining power of the model is weak. One of the reasons for the low value of $R^{2}$ is that mostly the expert involved in data collection are engaged in traditional procurement. They do not have much exposure to green procurement, and green procurement is rarely adopted, especially in the Pakistan construction industry. Thus, green procurement must be promoted in this industry. The MFT, i.e., category of market factors and techniques, is the most significant category to affect the adoption of green procurement in the construction industry with the highest $\beta$ value amongst all the paths, i.e., 0.155 .

\subsection{Assessment of Overall Model}

The model's global validity and illustrating ability are assessed. The goodness of fit (GoF) index value was used to make this determination. GoF is the geometric mean of average communality and average $R^{2}$ for both endogenous structures. This method is used to determine the evolved model's overall predictive ability [61]. The GoF value varies from 0 to 1 [62]. The GoF cut-off values were calculated using the rules of taking 0.50 as the communality value and various $R^{2}$ impact scales [63], as shown in Table 8. 
Table 8. GoF index and its criteria.

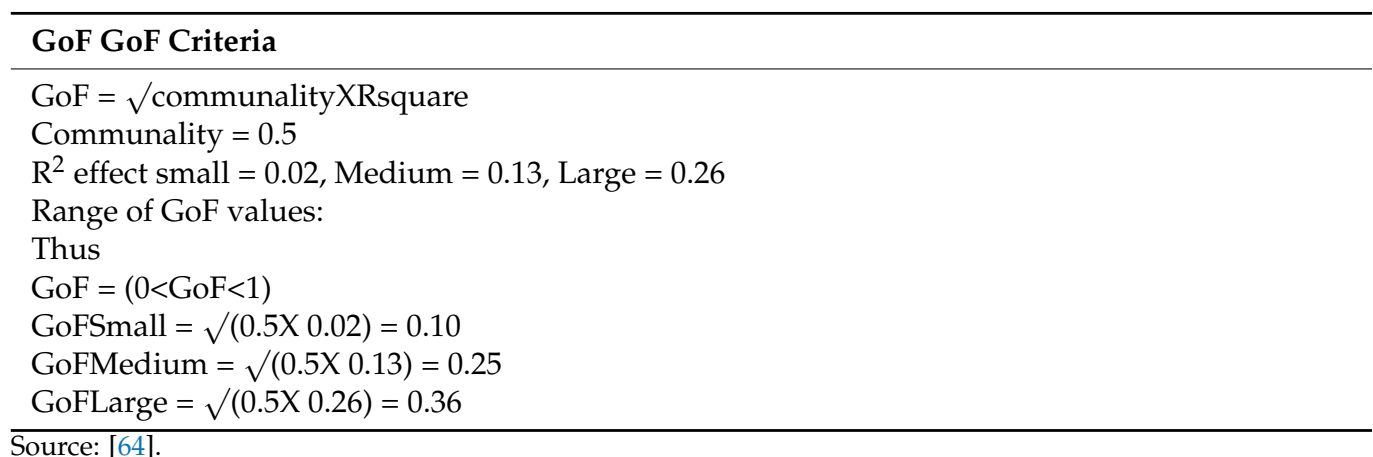

It can be observed that $\mathrm{GoF}_{\text {small }}(0.10), \mathrm{GoF}_{\text {medium }}(0.25)$ and $\mathrm{GoF}_{\text {Large }}(0.36)$ are cut-off values for assessing GoF index. Value of GoF was determined by the equation proposed by [65] as below:

$$
\begin{gathered}
\text { GoF }=\sqrt{ } \text { AVEXRSquare } \\
\text { GoF }=\sqrt{ }(0.612 \times 0.12) \\
\text { GoF }=0.27
\end{gathered}
$$

It can be analyzed that the evolved model's GoF value is 0.27 , which is higher than the necessary value for medium effect, as seen in Table 8 . It suggests that the evolved model has a moderate ability. The established model's strength can be further increased by providing more data samples from experienced professionals. Feedback from skilled professionals provides a more helpful contribution for evaluating the importance. The results of this study support the concept of green procurement and assists in promoting it. Green procurement initiatives are a way forward towards a sustainable construction industry.

\section{Conclusions}

This paper emphasizes the importance of green procurement adoption in the construction industry in general and particularly for Pakistan. A detailed quantitative approach was adopted to analyze the key factors for green procurement adoption in the construction industry of Pakistan. It is concluded that lack of knowledge and awareness of green procurement among construction practitioners are the key barriers to its adoption. Hence, it has become essential to take necessary action for promoting green procurement in the construction industry.

Several factors that can help promote green procurement in the construction projects of Pakistan were identified and prioritized in this study using SEM. The model showed that 'market factors and techniques' play a significant role in enhancing green procurement. Model results reveal that strategies adopted by competitors can enforce the practitioners for adopting new technologies. Strategies adopted by affiliated companies also play a vital role in enhancing green procurement practices. The owner should support the adoption of green procurement in the projects. The developed model was tested to check its validity and reliability. Outcomes of the study showed that the developed model has a weak level of explaining the power of the attributes while GoF revealed that overall it could exert a medium level of effect. It is essential to expand the use of green technology in procurement, market factors, and strategies.

Finally, further research is recommended to conduct confirmatory structural modeling and conduct a case study to assess the positive impacts of green material on project performance. Such research work will help the authorities develop strategies for selecting materials to achieve sustainability in the construction industry. 


\section{Practical Implication and Contribution}

This study identified significant factors contributing to the green procurement's adoption utilizing the partial least square approach to structural equation modeling, an advanced multivariate technique. The generated PLS-SEM model shows the influence of multiple factors on green procurement's adoption.

\section{Limitations and Future Studies}

This study was limited, from a data collection point of view, as it is focused on large cities of Sindh province only. Further, the model was developed based on the interviews and questionnaire survey amongst the construction industry practitioners. Since the adoption level of green procurement in the construction industry of Pakistan is low. Thus the practitioners participating in the data collection have theoretical knowledge but less awareness of the practical side of this key problem. Hence, this study can be further extended with the help of case studies. Additional research could also explore the best practices of green procurement's finest enactments in multiple construction projects. Furthermore, it could be fascinating to explore in the next stage whether a similar group of critical factors for green procurement's enhancement in the construction sector can be found in a different country.

Author Contributions: Writing, Review, and Project Administration, S.H.K.; Conceptualization, Writing, and Methodology, A.H.M.; Editing and Supervision, N.A.M.; Software, Formal Analysis, and Original Draft Preparation, A.A.; Supervision and Project Administration, T.H.A. All authors have read and agreed to the published version of the manuscript.

Funding: This research received no external funding.

Data Availability Statement: The data will be provided by the author on request.

Acknowledgments: The authors are thankful to Prince Sultan University, Riyadh, Saudi Arabia for providing financial assistance (Article Processing Charges) and academic support for this publication.

Conflicts of Interest: This paper has no conflict of interest.

\section{References}

1. Stasiak-Betlejewska, R.; Potkány, M. Construction Costs Analysis and its Importance to the Economy. Procedia Econ. Finance 2015, 34, 35-42. [CrossRef]

2. Talpur, M.A.H.; Napiah, M.; Chandio, I.A.; Khahro, S.H. Research Framework Focusing Transportation Accessibility Planning, Computer Based Modeling and Transportation Policy Outlines for Remote Regions of Developing World. Res. J. Environ. Earth Sci. 2013, 5, 32-40. [CrossRef]

3. Yan, H.; Shen, Q.; Fan, L.C.; Wang, Y.; Zhang, L. Greenhouse gas emissions in building construction: A case study of One Peking in Hong Kong. Build. Environ. 2010, 45, 949-955. [CrossRef]

4. Wong, J.K.; Li, H.; Wang, H.; Huang, T.; Luo, E.; Li, V. Toward low-carbon construction processes: The visualisation of predicted emission via virtual prototyping technology. Autom. Constr. 2013, 33, 72-78. [CrossRef]

5. Varnäs, A.; Berit, B.; Charlotta, F. Environmental consideration in procurement of construction contracts: Current practice, problems and opportunities in green procurement in the Swedish construction industry. J. Clean. Prod. 2009, 17.13, 1214-1222. [CrossRef]

6. Yllmaz, M.; Adem, B. Sustainability in construction sector. Sustain. Cities Soc. 2015, 195, 2253-2262. [CrossRef]

7. Thakur, A.K.; Pappu, A.; Thakur, V.K. Resource efficiency impact on marble waste recycling towards sustainable green construction materials. Curr. Opin. Green Sustain. Chem. 2018, 13, 91-101. [CrossRef]

8. Vyas, S.; Ahmed, S.; Parashar, A. BEE (Bureau of energy efficiency) and Green Buildings. Int. J. Res. 2014, 1, 23-32.

9. Dixon, W. The Impacts of Construction and the Built Environment; Briefing Notes; Willmott-Dixon Group: Letchworth Garden City, UK, 2010.

10. Bohari, A.A.M.; Skitmore, M.; Xia, B.; Teo, M.; Khalil, N. Key stakeholder values in encouraging green orientation of construction procurementThe path towards greening the Malaysian construction industry. J. Clean. Prod. 2020, 270, 1-11. [CrossRef]

11. Ali, T.H.; Akhund, M.A.; Memon, N.A.; Memon, A.H.; Imad, H.U.; Khahro, S.H. Application of Artifical Intelligence in Construction Waste Management. In 2019 8th International Conference on Industrial Technology and Management (ICITM); IEEE: Cambridge, UK, 2019; pp. 50-55. [CrossRef]

12. Yang, S.; Su, Y.; Wang, W.; Hua, K. Research on Developers' Green ProcurementBehavior Based on the Theory of Planned Behavior. Sustainability 2019, 11, 2949. [CrossRef] 
13. Kofoworola, O.F.; Gheewala, S.H. Estimation of construction waste generation and management in Thailand. Waste Manag. 2009, 29, 731-738. [CrossRef] [PubMed]

14. Salam, M.A. An empirical investigation of the determinants of adoption of green procurement for successful green supply chain management. In Proceedings of the 4th IEEE International Conference on Management of Innovation and Technology, (ICMIT), Bangkok, Thailand, 21-24 September 2008.

15. Alqadami, A.T.; Zawawi, N.A.W.A.; Rahmawati, Y.; Alaloul, W.; Alshalif, A.F. Key Success Factors of Implementing Green Procurement inPublic Construction Projects in Malaysia. IOP Conf. Ser. Earth Environ. Sci. 2020, 498, 012098. [CrossRef]

16. Zhu, Q.; Geng, Y.; Sarkis, J. Motivating green public procurement in China: An individual level perspective. J. Environ. Manag. 2013, 126, 85-95. [CrossRef] [PubMed]

17. Li, Y.; Xu, L.; Sun, T.; Ding, R. The impact of project environmental practices on environmental and organizational performance in the construction industry. Int. J. Manag. Proj. Bus. 2020, 13, 367-387. [CrossRef]

18. Wong, J.K.W.; Chan, J.K.S.; Wadu, M.J. Facilitating effective green procurement in construction projects: An empirical study of the enablers. J. Clean. Prod. 2016, 135, 859-871. [CrossRef]

19. Ali, Y.; Saad, T.; Sabir, M.; Muhammad, N.; Salman, A.; Zeb, K. Integration of green supply chain management practices in construction supply chain of CPEC. Manag. Environ. Qual. Int. J. 2020, 31, 185-200. [CrossRef]

20. Zhu, Q.; Sarkis, J. An inter-sectoral comparison of green supply chain management in China: Drivers and practices. J. Clean. Prod. 2006, 14, 472-486. [CrossRef]

21. Green Council. Report of the Research Study on the Current Status and Direction for Green Purchasing in Hong Kong; Green Council: Hong Kong, China, 2010.

22. Shen, L.; Zhang, Z.; Long, Z. Significant barriers to green procurement in real estate development. Resour. Conserv. Recycl. 2017, 116, 160-168. [CrossRef]

23. Faith-Ell, C. The Application of Environmental Requirements in Procurement of Road Maintenance in Sweden. Ph.D. Thesis, Land and Water Resources Engineering, Royal Institute of Technology, Stockholm, Sweden, 2005.

24. Musa, N.D.; Buniamin, S.; Johari, N.H.; Ahmad, N.; Hanim, F.; Abdul Rashid, A. Key indicators towards the implementation of green government procurement in Malaysia. World Appl. Sci. J. 2013, 28, 127-135.

25. Yu, T.; Shi, Q.; Zuo, J.; Chen, R. Critical factors for implementing sustainable construction practice in HOPSCA projects: A case study in China. J. Sustain. Cities Soc. 2018, 37, 93-103. [CrossRef]

26. Ofori, G. Greening the construction supply chain in Singapore. Eur. J. Purch. Supply Manag. 2000, 6, 195-206. [CrossRef]

27. Simion, C.P.; Nicolescu, C.; Vrîncut, M. Green Procurement in Romanian Construction Projects. A Cluster Analysis of the Barriers and Enablers to Green Procurement in Construction Projects from the Bucharest-Ilfov Region of Romania. Sustainability 2019, 11, 6231. [CrossRef]

28. Zhang, Y. Construction of Bid Evaluation Index System in Government Public Project Green Procurement in China Based on D-S Evidence Theory. Sustainability 2020, 12, 651. [CrossRef]

29. Walker, H.; Di Sisto, L.; McBain, D. Drivers and barriers to environmental supply chain management practices: Lessons from the public and private sectors. J. Purch. Supply Manag. 2008, 14, 69-85. [CrossRef]

30. Diabat, A.; Govindan, K. An analysis of the drivers affecting the implementation of green supply chain management. Resour. Conserv. Recycl. 2011, 55, 659-667. [CrossRef]

31. Yang, W.; Zhang, Y. Research on factors of green purchasing practices of Chinese. J. Bus. Manag. Econ. $2012,3,222-231$.

32. Rehman, U.U.; Shafiq, M.; Ali, H.; Abdullah, M. Green and sustainable construction practices impact on Organizational Development. Eur. J. Soc. Impact Circ. Econ. 2020. [CrossRef]

33. Adetunji, I.; Price, A.D.; Fleming, P. Achieving sustainability in the construction supply chain. Proc. Inst. Civ. Eng. Eng. Sustain. 2008, 161, 161-172. [CrossRef]

34. Love, P.E.; Irani, Z.; Edwards, D.J. A seamless supply chain management model for construction. Supply Chain Manag. Int. J. 2004, 9, 43-56. [CrossRef]

35. Testa, F.; Annunziata, E.; Iraldo, F.; Frey, M. Drawbacks and opportunities of green public procurement: An effective tool for sustainable production. J. Clean. Prod. 2016, 112, 1893-1900. [CrossRef]

36. Humphreys, P.; Matthews, J.; Kumaraswamy, M. Pre-construction project partnering: From adversarial to collaborative relationships. Supply Chain Manag. Int. J. 2003, 8, 166-178. [CrossRef]

37. Carter, C.R.; Dresner, M. Purchasing's role in environmental management: Cross-functional development of grounded theory. J. Supply Chain. Manag. 2001, 37, 12-27. [CrossRef]

38. Lam, P.T.; Chan, E.H.; Poon, C.S.; Chau, C.K.; Chun, K.P. Factors affecting the implementation of green specifications in construction. J. Environ. Manag. 2010, 91, 654-661. [CrossRef]

39. Ruparathna, R.; Hewage, K. Sustainable procurement in the Canadian construction industry: Challenges and benefits. Can. J. Civ. Eng. 2015, 42, 417-426. [CrossRef]

40. Russell, J. Underwriting process for construction contract bonds. J. Manag. Eng. 1992, 8, 63-80. [CrossRef]

41. Liu, B.; Huo, T.; Liao, P.C.; Yuan, J.; Sun, J.; Hu, X. A special Partial Least Squares (PLS) path decision modeling for bid evaluation of large construction projects. KSCE J. Civ. Eng. 2017, 21, 579-592. [CrossRef]

42. Durdyev, S.; Ihtiyar, A.; Banaitis, A.; Thurnell, D. The construction client satisfaction model: A PLS-SEM approach. J. Civ. Eng. Manag. 2018, 24, 31-42. [CrossRef] 
43. Memon, A.H.; Rahman, I.A. SEM-PLS Analysis of inhibiting factors of cost performance for large construction projects in Malaysia: Perspective of Clients and Consultants. Sci. World J. 2014, 165158. [CrossRef]

44. Becker, J.M.; Klein, K.; Wetzels, M. Hierarchical latent variable models in PLS-SEM: Guidelines for using reflective-formative type models. Long Range Plan. 2012, 45, 359-394. [CrossRef]

45. Hair, J.F.; Ringle, C.M.; Sarstedt, M. PLS-SEM: Indeed a silver bullet. J. Mark. Theory Pract. 2011, 19, 139-152. [CrossRef]

46. Hooper, D. Exploratory Factor Analysis. In Approaches to Quantitative Research-Theory and Its Practical Application; A Guide to Dissertation Students; Chen, H., Ed.; Oak Tree Press: Cork, Ireland, 2012.

47. Taofeeq, D.M.; Adeleke, A.Q.; Lee, C.K. Individual factors influencing contractors' risk attitudes among Malaysian construction industries: The moderating role of government policy. Int. J. Constr. Manag. 2019, 1-20. [CrossRef]

48. Hair, J.F., Jr.; Sarstedt, M.; Matthews, L.M.; Ringle, C.M. Identifying and Treating Unobserved Heterogeneity with FIMIX-PLS: Part I-Method. Eur. Bus. Rev. 2016, 28, 63-76. [CrossRef]

49. Sekaran, U.; Bougie, R. Research Methods for Business: A Skill Building Approach, 7th ed.; John Wiley \& Sons: Hong Kong, China, 2016.

50. Hulland, J. Use of partial least squares (PLS) in strategic management research: A review of four recent studies. Strateg. Manag. J. 1999, 20, 195-204. [CrossRef]

51. Geffen, C.; Rothenberg, S. Sustainable development across firm boundaries: The critical role of suppliers in environmental innovation. Int. J. Oper. Prod. Manag. 2000, 20, 166-186. [CrossRef]

52. Götz, O.; Liehr-Gobbers, K.; Krafft, M. Evaluation of structural equation models using the partial least squares (PLS) approach. In Handbook of Partial Least Squares; Springer: Berlin/Heidelberg, Germany, 2010; pp. 691-711.

53. Henseler, J.; Ringle, C.M.; Sinkovics, R.R. The use of partial least squares path modeling in international marketing. In New Challenges to International Marketing; Emerald Group Publishing Limited: Bingley, UK, 2009; pp. 277-319.

54. Chin, W.W. The partial least squares approach to structural equation modeling. Mod. Methods Bus. Res. 1998, 295, 295-336.

55. Hair, J.F.; Black, W.C.; Babin, B.J.; Anderson, R.E. Multivariate Data Analysis: Global Edition; Pearson: London, UK, 2010.

56. Aibinu, A.A.; Ling, F.Y.Y.; Ofori, G. Structural equation modelling of organizational justice and cooperative behaviour in the construction project claims process: Contractors' perspectives. Constr. Manag. Econ. 2011, 29, 463-481. [CrossRef]

57. Hair, J.F.; Risher, J.J.; Sarstedt, M.; Ringle, C.M. When to use and how to report the results of PLS-SEM. Eur. Bus. Rev. 2019, 31, 2-24. [CrossRef]

58. Hassan, A.K.; Adeleke, A.Q. The Effects of Project Triple Constraint on Malaysia Building Projects. Soc. Sci. Humanit. J. 2019, 3 , 1222-1238.

59. Ismayana, M.P.; Adeleke, A.Q. The Influence of Organizational Culture on Construction Risk Management Among Kuantan Malaysian Construction Industry: A Partial Least Square Structural Equation Modeling Approach. Soc. Sci. Humanit. J. 2020, 4, 1693-1704.

60. Cohen, J. Statistical Power Analysis for the Behavioral Sciences; Routledge: Oxfordshire, UK, 2013.

61. Wang, Y.M.; Chin, K.S. Some alternative models for DEA cross-efficiency evaluation. Int. J. Prod. Econ. 2010, 128, 332-338. [CrossRef]

62. Vinzi, V.E.; Trinchera, L.; Amato, S. PLS path modeling: From foundations to recent developments and open issues for model assessment and improvement. In Handbook of Partial Least Squares; Springer: Berlin/Heidelberg, Germany, 2010 ; pp. 47-82.

63. Wetzels, M.; Odekerken-Schröder, G.; Van, O.C. Using PLS path modeling for assessing hierarchical construct models: Guidelines and empirical illustration. MIS Q. 2009, 33, 177-195. [CrossRef]

64. Akter, S.; Ambra, J.D.; Ray, R. An evaluation of PLS based complex models: The roles of power analysis, predictive relevance and GoF index. In Proceedings of the Seventeenth Americas Conference on Information Systems (AMCIS 2011), Detroit, MI, USA, 4-8 August 2011.

65. Akter, S.; Ambra, J.D.; Ray, P. Trustworthiness in Health information services: An assessment of a hierarchical model with mediating and moderating effects using partial least squares (PLS). J. Am. Soc. Inf. Sci. Technol. 2011, 62, 100-116. [CrossRef] 